\title{
Masalah Etis dalam Proses Pengambilan Keputusan pada Praktik Pediatri
}

\author{
Sudigdo Sastroasmoro
}

\begin{abstract}
Masalah etika dalam praktik pediatri membawa masalah tersendiri karena ketidakmampuan sang pasien (bayi atau anak) untuk memberikan informed consent. Pada umumnya secara legal dan etis orangtua pasien dianggap sebagai pihak yang berhak memberikan persetujuan untuk tindakan pengobatan maupun diagnostik. Namun hal tersebut harus dibatasi selama tindakan orangtua tersebut memberi kebaikan pada anak, atau setidaknya tidak memperburuk keadaan pasien. Dokter anak harus siap dengan konsep informed consent (yang diberikan oleh anak remaja atau dewasa muda), parental permission (izin), serta meminta assent kepada anak untuk melakukan tindakan medis terutama yang bersifat traumatik, invasif, atau membawa bahaya tertentu. Dalam tiap kesempatan sebaiknya dokter anak selalu meminta persetujuan kepada pasien selama yang bersangkutan sudah memahami (meskipun sebagian) keuntungan dan kerugian bila suatu tindakan dilakukan atau tidak dilakukan. Kunci utama dalam pelaksanaan etika dalam praktik adalah komunikasi yang harus terselanggara dengan baik antara dokter, orangtua, dan anak. Implikasi legal dari perbuatan yang tidak etis dapat terjadi bila perbuatan dokter yang tidak etis tersebut menyebabkan kerugian di pihak pasien, baik morbiditas, mortalitas, atau kerugian material. Masalah etika dalam praktik menyangkut setiap langkah dalam pelayanan pasien, mulai dari appointment, anamnesis, pemeriksaan fisis, tindakan diagnostik, tindakan pengobatan, dan tindak lanjut. Rekam medis merupakan bagian dari tugas profesi dokter untuk menjalankannya dengan baik.

Banyaknya tuntutan terhadap apa yang sering dituduhkan sebagai malpractice harus diwaspadai, dan untuk sebagian berkaitan langsung dengan masalah etika itu sendiri.
\end{abstract}

Kata kunci: etika, informed conent, parental permission, parental assent, komunikasi.

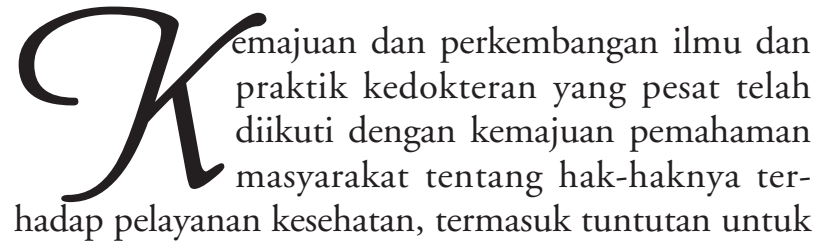

Alamat korespondensi:

Prof. DR. Dr. Sudigdo Sastroasmoro, Sp.A (K).

Divisi Kardiologi Departemen Ilmu Kesehatan Anak FKUI-RSCM, Jl. Salemba 6, Jakarta 10430

Tel. 314 7342, 315 5742, Fax. 3907743 memperoleh pelayanan terbaik, efektif, dan efisien serta aman. ${ }^{1}$ Tidak kurang pula kemajuan tuntutan masyarakat akan haknya untuk memperoleh penjelasan yang komprehensif tentang rencana tindakan pencegahan, diagnostik, maupun terapeutik sebelum tindakan dilakukan, termasuk hak untuk menolak dilakukannya suatu tindakan.

Dari pengamatan dan pengalaman sehari-hari kita melihat bahwa pada umumnya sebagian besar rencana dokter yang dipandu oleh etika kedokteran untuk melakukan yang terbaik kepada pasien berjalan selaras 
dengan kebutuhan dan pemahaman pasien akan kebutuhan tersebut. Oleh karenanya sebagian besar praktik seperti yang direncanakan oleh dokter dapat berlangsung dengan baik. Namun tidak jarang terdapat konflik antara rencana dokter di satu sisi dengan pendapat dan preferensi pasien di lain sisi. Bila hal ini terjadi maka dokter sebagai pihak yang paling berperan dalam praktik kedokteran harus memahami dan merujuk kembali pada hal-hal yang berkaitan dengan etika praktik, termasuk hak-hak pasien yang perlu dihormati.

Dalam perkembangannya, masalah etika makin dipengaruhi oleh banyak hal. ${ }^{1}$ Kemajuan dalam kedokteran membawa perubahan serta masalah etika tersendiri; terdapat hal-hal yang dahulu dianggap tidak etis sekarang berkembang menjadi etis, sebaliknya ada hal-hal yang dahulu dianggap etis sekarang menjadi tidak etis. Kemajuan masyarakat secara keseluruhan mengakibatkan berkembangnya kemampuan penguasaan materi kedokteran dan kesehatan pada sebagian orang. Hal ini ditunjang oleh berkembangnya sistem informasi dan komunikasi, baik melalui media massa cetak, elektronik, serta internet.

Perhatian yang makin meningkat akhir-akhir ini terhadap hak asasi manusia yang juga merupakan perhatian pelbagai badan dunia menjadikan masalah etika dalam praktik kedokteran menjadi semakin kompleks. Demikian pula perubahan dan perkembangan sistem kesehatan di masing-masing negara membawa konsekuensi etis (dan legal) dalam pelayanan terhadap pasien. Hal ini juga berkaitan dengan ekonomi kesehatan, termasuk pembiayaan pelayanan kesehatan masyarakat.

Masalah etika dalam praktik dapat timbul sejak masa sebelum konsepsi (misalnya pemeriksaan genetika pranikah) sampai dengan saat-saat terakhir dokter merawat pasien menjelang ajal (termasuk kapan harus menghentikan pengobatan), atau bahkan saat seorang pasien telah meninggal (misalnya masalah donor organ). ${ }^{2,3}$

Dokter anak sebagai anggota praktisi kedokteran tentu menghadapi masalah yang sama. Bahkan masalah tersebut menjadi lebih besar karena alasan yang nyata: sebagian besar pasien pediatri belum dianggap cukup mampu untuk menentukan sikap apakah ia akan menerima atau menolak tindakan yang akan dilakukan kepadanya. Atas alasan inilah maka para dokter anak diharuskan memahami etika praktik pediatri selain memahami etika praktik secara umum.
Makalah ini membahas secara ringkas beberapa hal penting tentang pengambilan keputusan klinis dalam praktik pediatri, disesuaikan dengan keadaan mutakhir yang berkembang dalam masyarakat kita. Pada akhir uraian disajikan beberapa contoh masalah etika dalam praktik pediatri yang dijumpai sehari-hari.

\section{Pediatri sebagai disiplin tersendiri}

Spesialisasi ilmu kesehatan anak pada awalnya merupakan bagian dari spesialisasi ilmu penyakit dalam. Kesadaran untuk memisahkan pediatri dari ilmu penyakit dalam diawali dengan pemahaman bahwa terdapat aspek khas dalam pediatri yang "tidak terdapat" dalam disiplin ilmu penyakit dalam, yakni aspek pertumbuhan dan perkembangan atau tumbuhkembang.

Dalam bahasa yang lazim digunakan, "anak bukanlah orang dewasa dalam bentuk mini”. Kalimat ini memperlihatkan bahwa meskipun secara umum semua organ pada anak sama fungsinya dengan organ dewasa, namun semua organ pada anak masih dalam tahapan pertumbuhan dan perkembangan, sesuai dengan aspek fisiologis anak. Jadi bukan hanya bentuknya saja yang kecil, namun kualitas fungsinya pun berbeda, sesuai dengan tahapan pertumbuhan dan perkembangannya. Ukuran anatomis yang normal untuk manusia dewasa dapat dianggap abnormal untuk anak, dan sebaliknya. Tidak hanya itu; hasil laboratorium dan pemeriksaan penunjang yang normal untuk bayi atau anak tidak berarti normal pula untuk ukuran dewasa. Sebagai contoh, kadar kalium serum pada bayi baru lahir adalah tinggi, sampai $7 \mathrm{mEq} / \mathrm{liter}$; dengan kadar ini seorang dewasa dapat mengalami fibrilasi yang mengancam kehidupan. Demikian pula gambaran EKG yang normal untuk bayi, bila diterapkan pada orang dewasa akan disimpulkan sebagai sangat abnormal.

Tingkat perkembangan mental pasien juga membawa akibat perlunya modifikasi dalam pendekatan diagnostik dan terapeutik. Kemajuan praktik kedokteran mengharuskan pasien berhak untuk memperoleh penjelasan sebelum memberikan persetujuan (informed consent). Hal yang sama juga berlaku dalam praktik pediatri. Namun karena bayi dan anak kecil belum mampu memberikan consent maka perlakuannya juga berbeda. Pada umumnya orangtua pasien dainggap mempunyai hak dan 
kewajiban moral dan legal untuk memberikan persetujuan tindakan yang akan diberikan kepada anaknya. ${ }^{4}$

\section{Dasar-dasar etika praktik kedokteran}

Pada umumnya kontrak antara pasien dan dokter dimulai dengan wawancara antara dokter dengan pasien. Selain mendengar keluhan dan riwayat penyakitnya, pada kesempatan tersebut dokter harus dapat menangkap apa maksud pasien berkonsultasi, dengan kata lain dokter harus mengerti benar harapan pasien. Bila dokter menyanggupi untuk memenuhi harapan pasien, maka kontrakpun terjadilah. Dalam tahapan ini dokter secara implisit menyatakan bahwa ia mempunyai kompetensi untuk mengatasi masalah pasien, dan ia bersedia untuk memberikan pelayanan terbaik dan etis. Di lain sisi pasien juga berkewajiban untuk bekerja sama dengan dokter, dalam arti mengikuti petunjuk atau instruksi dokter yang berkaitan dengan tindakan atau pengobatan yang telah dijelaskan dan disetujui sebelumnya. ${ }^{1}$

Sebagai tenaga profesional dokter harus senantiasa mendasarkan tugasnya pada profesionalisme yang dapat dipandang memiliki dimensi kompetensi, akuntabilitas, altruisme, kolegialitas, serta etika. Tiap dimensi tersebut dapat diuraikan menjadi komponenkomponen yang relevan. Dalam etika hubungan dokter-pasien, terdapat 4 hal utama atau asas yang menjadi landasan bagi dokter, yakni asas beneficence, non-maleficence, justice, dan autonomy. ${ }^{1,4}$ Meskipun asas-asas tersebut tampak sederhana dan mudah dimengerti, namun penerapannya dalam praktik tidak jarang menimbulkan konflik, dari yang paling sederhana sampai yang paling kompleks; lebih-lebih bila diingat bahwa tidak semua praktik kedokteran didasarkan pada evidence yang kuat.

Salah satu contoh yang cukup kontemporer adalah masalah sirkumsisi pada neonatus lelaki. Di negaranegara Barat praktik ini dahulu dilakukan secara luas oleh para dokter, dengan asumsi: (1) sirkumsisi dapat mengurangi kejadian kanker penis, (2) sirkumsisi pada lelaki dapat mengurangi kejadian kanker serviks pada pasangannya. Namun kemudian ternyata bahwa kedua hal yang dijadikan alasan utama tersebut tidak memiliki evidence yang sahih. Karenanya sirkumsisi non-terapeutik, yang dulu dianjurkan sekarang menjadi wacana, bahkan di banyak negara telah dinyatakan sebagai praktik yang tidak etis, karena: ${ }^{5}$

1. Asas beneficence (menguntungkan) tidak terpenuhi karena tidak terdapat evidence yang valid bahwa tindakan tersebut bermanfaat.

2. Asas non-maleficence (tidak merugikan) juga tidak dipenuhi karena tindakan bedah, bagaimanapun kecilnya, menyebabkan rasa sakit dan membawa potensi risiko terjadinya efek samping, misalnya perdarahan, infeksi, atau reaksi alergi akibat obat anestsi.

3. Asas justice (keadilan) tidak terpenuhi karena di luar kehendaknya bayi telah dirampas bagian tubuhnya yang utuh dan masih berfungsi.

4. Asas autonomy (autonomi) jelas tidak dipenuhi oleh karena izin untuk melakukan sirkumsisi tidak diberikan oleh bayi, melainkan secara 'proxy' oleh orangtuanya.

Catatan: Sirkumsisi atas alasan agama atau kepercayaan dikesampingkan dalam hal ini.

\section{Beberapa pertimbangan dalam proses pembuatan keputusan dalam praktik pediatri}

Para dokter telah memahami bahwa untuk melakukan tindakan medis, baik diagnostik maupun terapeutik yang mengandung risiko diperlukan informed consent, atau persetujuan setelah penjelasan. Hal ini tidak dapat diberlakukan kepada pasien anak; karenanya diperlukan pihak lain yang dianggap dapat "mewakili" pasien bayi atau anak untuk keperluan tersebut. ${ }^{1,4,6,7}$ Di lain sisi sulit diterima untuk mengatakan bahwa orangtua mempunyai hak penuh untuk mewakili anak dalam memberikan informed consent. Besarnya masalah perlakuan salah dan penelantaran anak (child abuse and neglect) mengingatkan kita bahwa tidak semua orangtua atau pengasuh memberikan yang terbaik untuk anak. ${ }^{8}$

Anak bukanlah bagian dari orangtuanya. Ia merupakan individu terpisah. Ia memiliki hak-hak yang dimiliki oleh orang dewasa. ${ }^{9,10,11}$ Dokter dan orangtua tidak dapat menafikan hak anak. Bila seseorang ayah atau ibu membawa anaknya ke dokter, yang menjadi pasien adalah sang anak, bukan orangtuanya. Karenanya tanggung jawab utama dokter juga harus kepada pasiennya, anak tersebut, bukan kepada orangtuanya. Pasien anak harus menjadi 
pertimbangan utama dokter. Dengan demikian maka keputusan untuk melakukan atau tdak melakukan sesuatu harus mengacu pada kepentingan anak, bukan orangtua atau yang membawa anak berobat. Dokter tidak boleh membuat keputusan untuk pasiennya semata-mata karena keinginan orang lain, meskipun orang lain itu adalah orangtua pasien, dengan mengabaikan dampaknya terhadap pasien. Hak orangtua untuk memutuskan sesuatu dalam pelayanan medis harus dibatasi pada keputusan yang menguntungkan anak.

Pemahaman atas hak-hak anak juga membawa pada anjuran agar prosedur yang tidak esensial harus ditunda sampai anak dapat memberikan consent-nya. Anak harus dilindungi terhadap tindakan yang tidak perlu, dan sedapat mungkin disertakan dalam decision making process. Dokter harus selalu mencari izin orangtua, namun dalam keadaan tertentu harus siap untuk mencari pendapat hukum bila keputusan oangtua membawa anak pada risiko yang substansial.

\section{Konsep informed consent, parental per- mission, dan child's assent}

\section{Informed consent}

Informed consent hanya dapat diberikan oleh orang dewasa yang telah mempunyai kemampuan untuk menerima dan mencernakan penjelasan dari dokter. Pada sebagian besar pasien anak hal tersebut belum dapat diberlakukan. Autonomy pasien sebagai asas penting dalam etika hubungan dokter-pasien mengandung unsur penjelasan yang benar dan lengkap, keterbukaan, dan informed consent. Hal terakhir inilah yang tidak dimilik oleh anak, sehingga ia diwakili oleh orangtua atau pengasuhnya.

Pada umumnya informed consent diperoleh dengan langkah-langkah sebagai berikut: ${ }^{12}$ (1) Dokter memberikan informasi yang akurat dan lengkap mengenai keadaan medis pasien, jenis, sifat dan tujuan tindakan, serta risiko tindakan tersebut bila dilakukan atau bila tidak dilakukan. (2) Dokter meyakini bahwa informasi tersebut telah dipahami oleh pasien; (3) Dokter memastikan bahwa pasien berada dalam keadaan mampu untuk mengambil keputusan; (4) Dokter meyakini, sedapat mungkin, bahwa pasien memberikan keputusan tanpa paksaan atau manipulasi. $^{1,4}$
Pendekatan yang lazim dilakukan terhadap pasien dewasa tersebut dapat diterapkan pada kelompok remaja yang dianggap sudah memiliki kemampuan untuk memahami informasi dan mengambil keputusan. Biasanya anak yang berusia 14 tahun atau lebih sudah layak untuk memberi informed consent, namun harus disesuaikan dengan kondisi perkembangan individual, besarnya masalah, risiko tindakan yang akan dilakukan, dan definisi hukum setempat.

\section{Parental permission}

Bayi dan anak kecil jelas tidak dapat memberikan informed consent. Karenanya proses pengambilan keputusan dalam praktik pediatri menjadi tanggung jawab bersama antara dokter dan orangtua. Orangtua pada umumnya dianggap secara legal dan etika memiliki hak untuk memilih tindakan yang terbaik bagi anaknya. ${ }^{7}$ Dalam keadaan ini dokter harus berusaha memperoleh izin orangtua (parental permission) untuk melakukan tindakan medis kepada pasien bayi dan anak. Proses untuk memperoleh parental permission ini sama dengan proses untuk memperoleh informed consent yang diuraikan di atas. ${ }^{4,13}$

Perlu diingatkan kembali bahwa beberapa faktor harus menyebabkan dokter waspada terhadap keputusan orangtua, termasuk keterbatasan penguasaan orang awam terhadap ilmu kedokteran, terdapatnya kasus perlakuan salah terhadap anak. Halhal tersebut, selain faktor agama, kepercayaan, tradisi dalam pengasuhan anak, dapat membawa orangtua untuk menolak dilakukannya tindakan pencegahan, diagnostik, dan terapi yang diperlukan oleh anak, padahal tindakan tersebut dapat menyelamatkan jiwa anaknya. Dengan kata lain pilihan yang dilakukan oleh orangtua mungkin bukan yang terbaik untuk anaknya dipandang dari segi kedokteran.

\section{Informed assent}

Bila yang dihadapi adalah anak yang lebih besar atau remaja, maka proses pengambilan keputusan menjadi sedikit berbeda. Dokter harus membimbing orangtua agar pengambilan keputusan dilakukan dengan melibatkan anak dalam suatu proses interaktif. Inilah yang disebut dengan child's assent. ${ }^{4}$ Besarnya peran anak dalam proses pengambilan keputusan ini sangat tergantung pada tingkat perkembangan anak, dengan 
merujuk pada kemampuannya untuk memahami informasi yang diberikan dan kemampuannya mengambil keputusan berdasarkan informasi yang diberikan tersebut. Selama proses interaktif antara dokter, orangtua, dan anak ini dokter harus lebih bijak dalam menggunakan kata dan istilah agar mudah dimengerti oleh anak. Dokter juga harus jeli untuk menilai bagaimana kemampuan anak menerima informasi, reaksi anak selama dan setelah diberikan informasi, serta tingkat kemandiriannya dalam memberikan pendapat atau keputusan.

Pengecualian terhadap keperluan memperoleh consent, permission, atau assent dapat berbeda antara satu negara dengan negara lainnya. Pengecualian dapat diklasifikasi berdasarkan pelbagai aspek: ${ }^{1,4,14,15}$

1. Pengecualian atas dasar keadaan gawat darurat. Untuk pelayanan gawat darurat, lebih-lebih terhadap keadaan yang membahayakan jiwa, tidak diperlukan consent atau permission, namun dokter wajib berusaha untuk memperolehnya segera setelah keadaan memungkinkan.

2. Pengecualian atas dasar emansipasi. Seorang yang masih dikategorikan sebagai anak (menurut Konvensi Hak Anak adalah di bawah usia 18 tahun) dianggap independen dan dapat memberikan consent bila: ia sudah menikah, remaja dalam dinas militer, remaja yang diberi hak oleh pengadilan, mereka yang hidup terpisah dari orangtua dan secara finansial independen. Remaja hamil atau remaja yang telah memiliki anak juga dianggap telah mampu memberikan consent.

3. Pengecualian atas dasar asumsi bahwa remaja telah kompeten (mature minor): remaja berusia 14 tahun atau lebih dapat dipertimbangkan layak memberikan consent sepanjang dokter meyakni bahwa yang bersangkutan dapat memahami jenis, manfaat, risiko tindakan dan lain-lain yang akan dilakukan terhadap dirinya. Dalam hal ini yang harus amat dipertimbangkan adalah risiko tindakan yang akan dilakukan serta kemampuan pasien. Bila terdapat keraguan hendaknya dimintakan izin kepada orangtua.

4. Pengecualian atas dasar keadaan medis tertentu: remaja yang mencari pertolongan kesehatan jiwa, pelayanan kontrasepsi, pemeriksaan HIV, penyakit menular seksual, konsultasi ketergantungan obat, luka akibat perbuatan kriminal, dan sebagainya.

\section{Beberapa contoh}

1. Hal yang sehari-hari dihadapi oleh dokter anak memberikan nasihat makanan bayi, dalam hal ini air susu ibu (ASI). Asas utama dalam etika kedokteran "memberikan yang terbaik kepada pasien" mengandung arti bahwa dokter (anak) harus senantiasa menganjurkan agar setiap ibu yang baru melahirkan memberikan ASI kepada bayinya. Banyaknya keuntungan dan nyaris tidak adanya kerugian pemberian ASI merupakan jaminan bahwa ASI memang yang terbaik untuk bayi. Namun tidak jarang sang ibu (terus terang atau tersembunyi) enggan untuk memberikan ASI, atau hanya mau sekedarnya ("kalau nanti cukup ASI-nya"). Dalam hal ini dokter harus memberikan waktu yang cukup untuk memotivasi pemberian ASI dengan alasan yang akurat dan jelas. Dokter yang tidak melakukan upaya ini dapat dianggap melanggar etika. ${ }^{16,17}$

2. Peserta Program Dokter Spesialis (PPDS) Departemen Ilmu Kesehatan Anak sering menjumpai orangtua yang menolak tindakan pungsi lumbal untuk anaknya guna memastikan diagnosis meningitis bakterialis. Meskipun upaya untuk memperoleh izin harus dilanjutkan, namun jangan sampai hal tersebut menunda terlalu lama (misalnya menunggu kedatangan neneknya dari kampung) untuk memberikan antibiotik yang adekuat guna mengatasi meningitisnya setelah memberikan penjelasan kepada orangtua kenapa antibiotik harus cepat diberikan. Ada pula orangtua yang menolak anaknya dirawat untuk terapi yang adekuat, dan memilih membawa pulang anaknya yang sakit berat dengan alasan akan dibawa ke dukun atau menjalani upacara keagamaan tertentu. Segala cara yang mungkin harus diupayakan agar anak dapat dirawat dan diobati. Dalam hal seperti ini paling tidak dokter jaga harus melakukan konsultasi kepada dokter yang lebih senior. Di negara-negara maju upaya yang dilakukan dapat sampai ke pengadilan.

3. Contoh lain adalah penolakan orangtua pasien terhadap imunisasi yang akan diberikan kepada anaknya. Dalam beberapa tahun terakhir ini para dokter bersilang pendapat tentang peran vaksinasi tertentu terhadap kejadian autisme. Karena masalah ini mendapat publikasi yang luas baik di media massa maupun di internet, banyak orangtua pasien yang menolak diberikan imunisasi, misalnya 
imunisasi MMR. Bahkan sebagian kecil orangtua menolak pemberian imunisasi apapun yang mengandung timerosal, bahan preservasi beberapa jenis vaksin. Untuk jenis imunisasi yang belum diharuskan, masalahnya tidak terlalu serius; namun untuk jenis vaksin yang diharuskan seperti DPT dan hepatitis- $B$, sikap orangtua tersebut jelas mengancam kesehatan dan keselamatan tidak saja bagi anak namun mungkin juga bagi masyarakat umum.

4. Seorang remaja berusia 12 tahun didiagnosis dengan pasti bahwa ia menderita demam reumatik akut. Konsekuensinya ia harus memperoleh perlindungan terhadap infeksi Streptococcus beta-hemolyticus, yakni penisilin benzatin setiap bulan, setidaknya selama 5 tahun. Bila pasien menolak untuk disuntik dan memilih untuk diberi obat oral (penisilin V, eritromisin, sulfa) sedangkan orangtua memilih untuk diberikan suntikan, bagaimana sikap dokter? Dokter harus menjelaskan keuntungan pemberian suntikan yakni pemberiannya dapat dikontrol dan tidak menyebabkan resistensi kuman streptokok terhadap penisilin. Sebaliknya remaja yang selama bertahun-tahun harus minum obat sedangkan ia sama sekali tidak merasa sakit dapat menyebabkannya enggan atau bosan atau tidak melakukannya dengan teratur. Akibatnya pemberian menjadi tidak terkontrol. Di lain sisi banyak juga dilaporkan resistensi kuman bila diberikan obat oral. Dalam kasus ini dapat saja ibu mengabaikan pendapat anaknya dengan konsekuensi terjadi dampak terhadap hubungan antara ibu dan anak, terutama bila anak menganggapnya merupakan beban yang berat.

5. Tidak jarang seorang anak datang ke Unit Gawat darurat anak tanpa diantar oleh orangtua atau pengasuhnya. Bila keadaannya memang gawat darurat tidak diperlukan izin untuk melakukan tindakan terapeutik yang menyelamatnya jiwa. Bagaimana dengan anak perempuan berusia 14 tahun yang datang dengan teman lelakinya dan minta dilakukan tes kehamilan?

6. Masalah yang paling pelik (setidaknya bagi penulis) adalah ketika dokter anak dihadapkan pada bayi baru lahir dengan kelainan kongenital multipel. Perkembangan ilmu dan pengobatan telah menggeser pendapat medis. Beberapa dasawarsa yang lalu bayi dengan sindrom Down dengan penyakit jantung bawaan cenderung untuk dinasihatkan tidak usah dikoreksi kelainan jantungnya. Namun dewasa ini anak dengan sindrom Down dan penyakit jantung bawaan yang dikoreksi kelainan jantungnya dapat hidup bahagia mendekati anak normal. Contoh tersebut dapat membuat dokter ragu untuk memberi nasihat medis apakah sebaiknya bayi dengan kelainan bawaan tertentu diberikan pengobatan maksimal ataukah diberikan pengobatan minimal karena prognosisnya buruk sekali.

Contoh-contoh di atas merupakan sekelumit dari masalah etika yang dapat ditemukan dalam praktik sehari-hari. Seribu satu kasus yang unik dapat timbul, yang seringkali sejalan dengan perubahan sosial dalam masyarakat. Dokter anak tidak jarang menjumpai masalah etika ketika menghadapi bayi baru lahir dengan golongan darah yang tidak kompatibel dengan golongan darah ayah, atau ayah dan ibu bayi sudah bercerai, atau pendapat ayah dan ibu pasien saling bertentangan, dan sebagainya. Belum lagi budaya keluarga batih di tanah air, yang memungkinkan peran anggota keluarga lain (khususnya kakek, nenek) menjadikan masalah proses penghambilan keputusan lebih kompleks.

Dimensi etika dalam kedokteran sepintas tampak sebagai masalah yang universal, namun dalam praktik tidak demikian halnya. Jangankan lintas-negara; perbedaan dapat terjadi antara negara bagian dalam satu negara. Seperti telah disebut di atas, masalah etika bukan masalah yang statis; ia merupakan produk dari banyak faktor, baik medis maupun non-medis. Karenanya sesuai dengan dimensi profesionalisme, pemahaman dokter anak terhadap masalah etika dalam praktik harus memperoleh prioritas yang tinggi.

Akhir-akhir ini, dimensi ketiga etika mulai dibicarakan, yaitu kepentingan generasi masa depan. Walaupun keputusan medis yang dibuat saat ini berdampak besar pada kesehatan generasi mendatang, hal ini belum menjadi isu popular dalam perdebatan etika kedokteran. Misalnya masalah lingkungan hidup yang saat ini masih sering diabaikan dalam pertimbangan medis, padahal lingkungan hidup berperan besar dalam kesehatan anak-cucu kita. Kesehatan generasi yang akan datang menjadi tanggung jawab seorang dokter yang tak kalah pentingnya dengan kesehatan pasien dan masyarakat saat ini. ${ }^{18}$ 


\section{Daftar Pustaka}

1. ACP Ethics and Human Rights Committee. Ethics manual. Ann Intern Med 1998;128:576-94.

2. Savulescu J. Is there a "right not to be born"? Reproductive decision making, options and the right to information. J Med Ethics 2002;28:65-7.

3. Burns JP, Mitchell C, Griffith JL. End-of-life care in the pediatric care unit: Attitude practices of pediatric critical care physicians and nurses. Crit Care Med 2001;29

4. Committee on Bioethics. Informed consent, parental permission, and assent in pediatric practice. Pediatrics 1995;95:314-7.

5. CIRP. The bioethics of the circumcision of male children. 2004 Aug 26. Available from: URL: http:// www.cirp.org/library/ethics.

6. Nelson RM, Fost N. Ethics in pediatric care. In: Behrman RE, Kliegman RM, Jenson HB, editors. Nelson textbook of pediatrics. $17^{\text {th }}$ ed. Philadelphia: WB Saunders; 2004. p. 6-10.

7. Webb E. Health services: who are the best advocates for children. Arch Dis Child 2002;87:175-7.

8. David TJ. Avoidable pitfalls when writing medical reports for court proceedings in cases of suspected child abuse. Arch Dis Child 2004;89:799-804.

9. United Nations Organization. United Nations Convention on the Rights of Children.

10. Lansdown G. Implementing children's rights and health. Arch Dis Child 2000;83:286-8.

11. Webb E. Discrimination against children. Arch Dis Child 2004;89:804-8.

12. Samil RS. Etika Kedokteran Indonesia. Jakarta: Yayasan Bina Pustaka Sarwono Prawirohardjo. Jakarta, 2001.

13. University of Washington, School of Medicine. Ethic cases 2000-2001. Diunduh dari http://www.cmaj.calmiscl bioethics.shtml

14. American Academy of Pediatrics, Committee on Pediatric Emergency Medicine. Consent for emergency medical services for children and adolesecents. Pediatrics 2003;111:703-6.

15. Fallat M, Donovan GK. Ethical and legal considerations in pediatric surgery. Diunduh dari http://emedicine.com. Diakses tanggal 25 November 2004.

16. Gatrad AR, Sheikh A. Medical ethics and Islam: principles and practice. Arch Dis Child 2001;84:72-5.

17. Yurdakok M. Pediatric ethics in the holy Quran. Letter. Arch Dis Child 2001; 85:79.

18. Marais BJ. Ethics; the third dimension. Letter. Arch Dis Child 2004;89:1077-8. 